$\begin{array}{llllllll}R & E & S & E & N & H & A & S\end{array}$

Considero a coletânea um estímulo à reflexão sobre as diferentes experiências relacionadas a processos cartográficos no Brasil, assim como ao debate crítico sobre os usos das novas tecnologias, seus impasses e estratégias utilizadas em situações particulares de mapeamento. Tais contribuições certamente serão profícuas para o equacionamento dos desafios que os processos de cartografia contemporâneos trazem. Além do reconhecimento do território comum - questão de fundamental interesse na solução dos conflitos relacionados aos processos jurídicos de demarcação de terras e acesso aos recursos -, as potencialidades que as novas modalidades de cartografias participativas promovem são significativas, pois podem vir a revelar, de forma inédita, visões de mundo e marcadores simbólicos dos espaços pouco valorizados nas cartografias tradicionais, dando visibilidade a distintas modalidades de demarcação e aos usos sociais do espaço que processos democráticos ensejam.

\section{ESPAÇO PÚBLICO: DO URBANO AO POLÍTICO}

Sérgio Luís Abrahão

Ed. Annablume/Fapesp, 2008, 1aed.

Sarah Feldman

Professora livre docente do Programa de Pósgraduação em Arquitetura e Urbanismo da EESC-USP

O livro Espaço Público: do urbano ao político, de Sérgio Luís Abrahão, traz importantes contribuições para o debate e a reflexão sobre o espaço público - tema que, nas últimas duas décadas, vem mobilizando múltiplos campos disciplinares. O argumento que estrutura o livro é a atribuição de uma dimensão política à materialidade dos espaços urbanos, que Abrahão detecta como elemento persistente nos trabalhos desenvolvidos na área de Arquitetura e Urbanismo.

O autor situa a origem desta articulação na análise crítica do urbanismo modernista formulada na década de 1950. É a partir desse momento que, em oposição ao "espaço racionalizado", as relações sociais no espaço urbano são retomadas como valores positivos da vida urbana, e são mobilizados conceitos, métodos de interpretação do espaço e proposiçôes de urbanismo que levam à perspectiva do que o autor define como "uma forma de materializar no urbano o espaço político das sociedades democráticas" (p.177).

O autor historiciza a construção conceitual deste "espaço público político" a partir da interação de ideias formuladas no âmbito da filosofia, sociologia, antropologia, geografia com proposições urbanísticas. $\mathrm{O}$ percurso delineado por Abrahão destaca três momentos de inflexão nesse processo. Os Congressos Internacionais de Arquitetura Moderna (CIAMs), quando as bases para as propostas de "centros cívicos" e para projetos que conferem às ruas o estatuto de lugares de encontro e de reunião da comunidade são introduzidas por Jose Luis Sert, Siegfried Giedion e por arquitetos do Team X Group, como Peter e Allison Smithson. Os anos de 1960, período em que os estudos de Jane Jacobs e de Henri Lefebvre, pautados na observação da vida social orgânica e espontânea de comunidades, assim como os métodos analíticos desenvolvidos por Aldo Rossi, reforçam esta perspectiva humanista das cidades. E o período mais recente, em que esta dimensão humanista dá lugar a uma dimensão política que inclui a totalidade do território urbano. A cidade passa a ser entendida como lugar cívico. Amplia-se, nesse momento, o leque de abordagens sobre o espaço público que destacam os impasses e a crise dos valores contemporâneos. Estudos realizados por Michel Brill, Sharon Zukin, Gilles Lipovetsky e Rosalyn Deutsche expressam esta diversidade, que Abrahão qualifica como "polifonia". Nestas formulações, ganham importância concepçôes de espaço público moldadas nos campos da filosofia e das ciências sociais, destacandose os trabalhos de Hanna Arendt, Jürgen Habermas e Richard Sennet.

Ao mesmo tempo em que recupera esta trama conceitual, Abrahão detecta sua repercussão em investigaçōes e em experiências de planejamento urbano desenvolvidas no Brasil. Mostra a mudança da abordagem da rua, na década de 1970, para uma abordagem do espaço público, na década de 1990, e a relação deste deslocamento a contextos políticos diversos - o período militar e o período democrático, respectivamente. Mostra, ainda, que nos estudos realizados nos últimos vinte anos, prevalece o debate sobre o chamado "recuo do espaço público", associado às mudanças na produção e na gestão do espaço urbano determinadas pelo neoliberalismo. 
No que se refere ao debate brasileiro, o livro traz uma preciosa recuperação da figura do arquiteto Carlos Nelson Ferreira dos Santos. Em um capítulo inteiramente dedicado ao seu percurso intelectual e profissional, mostra seu pioneirismo como pesquisador e urbanista devotado à re-significação do espaço público como lugar político. $\mathrm{Na}$ análise dos trabalhos de Carlos Nelson desenvolvidos na Favela Brás de Pina, ainda como estudante, no bairro do Catumbi e no conjunto Selva de Pedra, nos anos de 1970, assim como na análise de sua dissertação de mestrado e de dezenas de textos que publicou em revistas especializadas, Abrahão apresenta os vínculos que manteve com a antropologia social, sua atuação política na prática do urbanismo, todas as referências internacionais que mobilizou em suas críticas ao que denominava "planejamento racionalista-progressista”, além do enfoque central dado à rua em seus projetos e reflexões.

Ao utilizar o percurso de Carlos Nelson como síntese da reflexão desenvolvida no Brasil sobre o espaço público político, o livro traz uma contribuição relevante para a historiografia do urbanismo, pois ajuda a compreender a combinação de fatores locais envolvidos na construção e a apropriação de ideias no campo do urbanismo.

Finalmente, gostaria de destacar um segundo plano de leitura permitido pelo livro. Na recuperação da trajetória do debate sobre o espaço público, em paralelo às evidências apontadas por Abrahão, pode-se distinguir um discurso exaltando os atributos e a retomada da vida das cidades tradicionais, estruturado de forma enfática e persistente em oposição aos princípios do Movimento Moderno. Há um determinismo nestas argumentaçōes que permite vislumbrar a construção do que John R. Gold chama "as grandes narrativas sobre o Movimento Moderno". ${ }^{1}$ Ou seja, há um discurso revelado de forma quase clandestina no livro, que explicita ambiguidades e simplificações em relação ao ideário construído nos CIAMs anteriores à década de 1950 que merecem ser exploradas.

1 Gold, John R. The Experience of Modernism. Modern architects and the future city 1928-1953. Londres. E \& FN Spon, 1997, pp.3-6. 